\title{
PAULOPHYTON FROM THE CARBONIFEROUS OF PARACAS, PERU: A RARE BUT WIDESPREAD FOSSIL PLANT WITH UNUSUAL MORPHOLOGY
}

\author{
ROBERTO IANNUZZI \\ Departamento de Paleontologia e Estratigrafia, Instituto de Geociências, Universidade Federal do Rio Grande do Sul, \\ Av. Bento Gonçalves, 9500, 91509-900, Porto Alegre, RS, Brazil.roberto.iannuzzi@ufrgs.br \\ HERMANN W. PFEFFERKORN \\ Department of Earth and Environmental Science, University of Pennsylvania, Philadelphia, 19104-6316, U.S.A. \\ hpfeffer@sas.upenn.edu \\ VERA ALLEMAN \\ Facultad de Ciencias Biológicas, Universidad Ricardo Palma, Av. Armendaria, 349, Lima 18, Peru. \\ vmealleman@yahoo.es
}

\begin{abstract}
Paulophyton has the appearance of an Early or Middle Devonian plant but is found in the Carboniferous. This report from Peru expands our knowledge of its unusual biogeographic distribution (Peru, Brazil, Argentina, Bolivia, and Germany) that includes the southern temperate Paracas realm (Gondwana) and the Carboniferous tropics (Euramerican Realm). Stratigraphically Paulophyton is known from the late Tournaisian (Mississippian) to the middle of the Pennsylvanian. It is an uncommon but apparently widespread plant characterized by leafless, thin axes with small, terminal sporangia. It is found mostly as very small fragments, a fact that makes it easy to overlook. Paulophyton may be the representative of a plant group that has otherwise not yet been recognized in the Carboniferous.
\end{abstract}

Key words: Paulophyton, late Visean, Paracas Realm, Ambo Group, La Mina Section, Peru.

RESUMO - Paulophyton é uma planta com aparência de outras encontradas no Devoniano Inferior e Médio, mas é registrada no Carbonífero. Este registro no Peru expande nosso conhecimento sobre a sua incomum distribuição biogeográfica (Peru, Brasil, Argentina, Bolívia e Alemanha) que inclui o reino temperado do sul (Paracas, parte do Gondwana) e os trópicos carboníferos (Reino Euroamericano). Estratigraficamente, Paulophyton é conhecido desde o final do Tournaisiano (Mississipiano) até o Pensilvaniano médio. Esta exótica, mas aparentemente bem distribuída planta é caracterizada pelos seus eixos finos e áfilos que suportam pequenos esporângios terminais. Ela é encontrada normalmente na forma de pequeníssimos fragmentos, um fato que faz com que seja facilmente negligenciada nas associações. Paulophyton pode ser o representante de um grupo vegetal que ainda não foi reconhecido no Carbonífero.

Palavras-chave: Paulophyton, final do Viseano, Reino Paracas, Grupo Ambo, Seção La Mina, Peru.

\section{INTRODUCTION}

Paulophyton Dolianiti, 1954 emend. Leguizamón \& Archangelsky, 1981 is a remarkable and enigmatic plant. It resembles Early Devonian Rhyniophytes or Middle Devonian Trimerophytes in appearance but occurs in the Carboniferous. It is known from only six areas in the world, including the report from Peru presented in this paper, but belongs to two major biogeographic realms, namely Gondwana and Euramerica (the Carboniferous tropics). Paulophyton is not a very conspicuous plant and is found most often in small fragments. It is suspected that it might be more widespread having been overlooked in some floras. Therefore, this contribution presents its recognition in the Paracas Peninsula, Peru, together with a comparison of all known occurrences as a starting point for a search for and interpretation of this unusual Carboniferous plant.

\section{STUDY AREA AND GEOLOGICAL SETTING}

Peruvian fossils described in this paper come from the La Mina section ( $13^{\circ} 54^{\prime} 55^{\prime}$ 'S $\left./ 76^{\circ} 18^{\prime} 57^{\prime} \mathrm{W}\right)$, an outcrop on the Paracas Peninsula on the southern coast of Peru (Figures 1A-C). The age assignment of the Paracas Carboniferous has a complex history. Early in the last century, the beds were called Late Carboniferous, but after 1930 they were considered Early Carboniferous (synthesis in Alleman, 1985). Part of the problem lies in the fact that only a few poorly preserved sporomorphs were recovered in Paracas so far. Despite this, they were considered to be indicative of an 
Early Carboniferous age (Doubinger \& Alvarez Ramis, 1980, Azcuy, 1991). Besides, the La Mina section consists of a 170 $m$ thick sequence of interlayered sandstones, siltstones, shales, and coals considered as belonging to the Ambo Group (Figure 1D). The detailed studies of the palynological content have pointed to a late Visean age for this unit in other areas of Peru (Azcuy \& di Pasquo, 2005, 2006).

On the other hand, all these rocks were deposited under a warm temperate climatic region (Alleman \& Pfefferkorn, 1988; Pfefferkorn \& Alleman, 1989) but previous age assignments were based on comparisons of Paracas plant megafossils with those from either the Euramerican (tropical) or Gondwana (cool temperate) floral realms. This warm temperate floral realm, the Paraca floral belt, existed only during the late Visean-earliest Serpukhovian and now can be dated clearly (using miospores, plant megafossils and radiometric datings) and recognized in other parts of Gondwana, e.g. Africa, India and Australia (Iannuzzi \& Pfefferkorn, 2002; Azcuy \& di Pasquo, 2005, 2006, Pfefferkorn et al., 2014).

Sedimentological studies of the La Mina section (Nuñez del Prado, 1991a,b) indicate that the lower beds (units 1-14) are fluvial deposits (Figure 1D). Channels and diverse floodplain environments characterize these beds. Units 15 through 19 and unit 23 were deposited in a coastal plain where tides in the freshwater environment controlled flooding and influenced other fluvial processes. Units 20 to 22 and probably unit 24 represent beach barrier bar complexes that protected the coastal plains. The fossiliferous beds of Unit 23 of the flood plain facies can be divided into four subunits. Paulophyton occurs with other plants, especially the lycopsid Tomiodendron, in subunit 23.3 (triangle in Figure 1D).

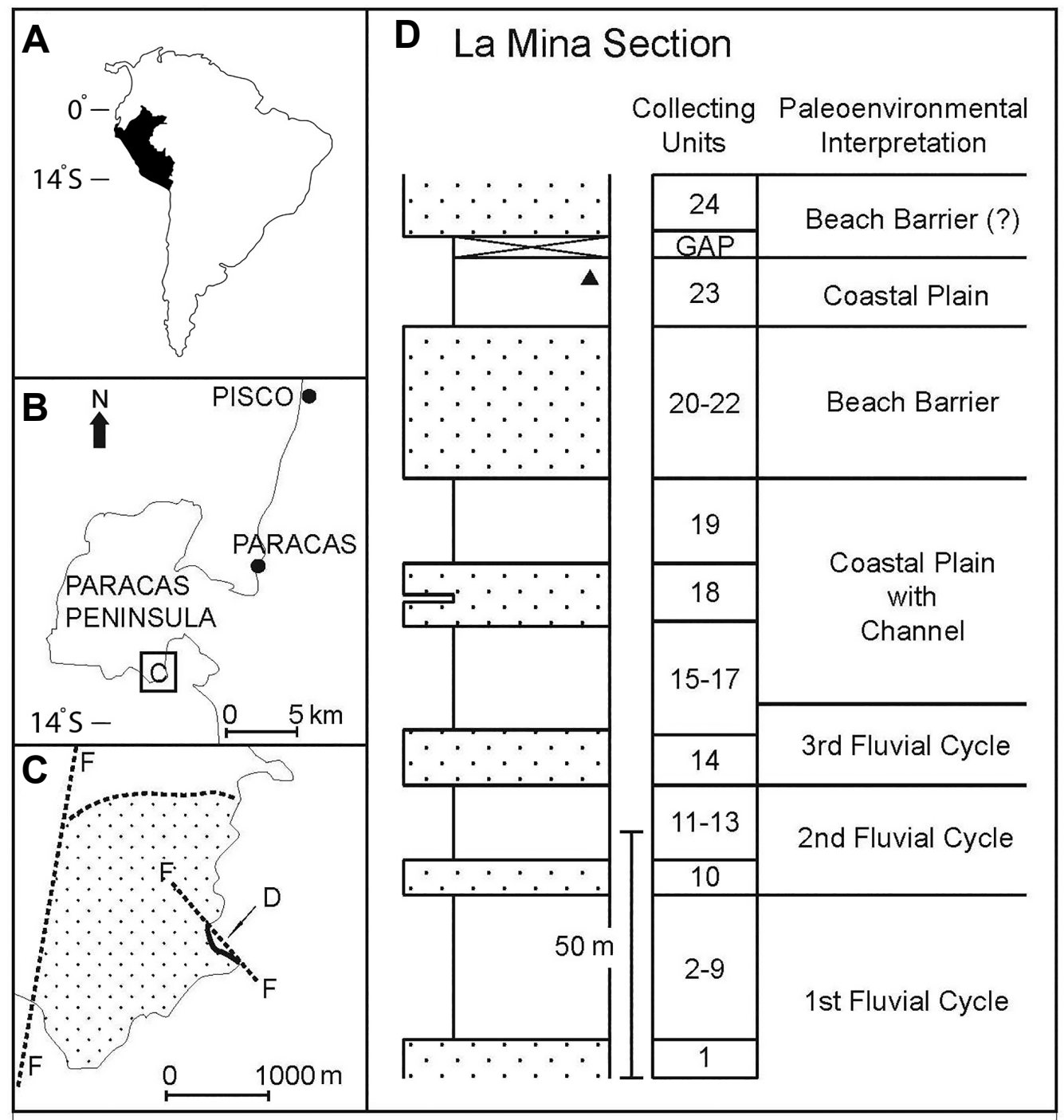

Figure 1. Location and stratigraphic section where Paulophyton was found in Peru. A, position of Peru in South America. B, location on the Paracas Peninsula. C, position of the La Mina section; dashed lines between letters F--F are faults; stippled area represents outcrop of Carboniferous beds; dashed line in North marks the cover by Tertiary rocks; thick line represents location of La Mina section which is shown in D. D, simplified graphic depiction of the La Mina section with indication of collecting units and paleoenvironmental interpretation; triangle marks the horizon in which Paulophyton was found; stippled layers are thicker sandstone beds including conglomeratic layers; other intervals consist of interlayered beds of sandstone/graywackes, siltstones, shales, and thin coals (modified from Pfefferkorn et al., 2014). 


\section{MATERIAL}

Material of Paulophyton includes different parts of the branching system and sporangia connected to terminal axes. All specimens are preserved as adpressions. So far the maceration of palynomorphs from the material has not been possible even though Doubinger \& Alvarez Ramis (1980) and Azcuy (1991) were able to extract badly preserved, but recognizable, spores and pre-pollen from bulk material at the Paracas locality. Specimens RPT-89-37 and 89145 are the property of the Natural History Museum of the Universidad Ricardo Palma in Lima, Peru. Specimen MP-Pb 4032 is in the paleobotanical collection of the Departamento de Paleontologia e Estratigrafia, Instituto de Geociências, Universidade Federal do Rio Grande do Sul, Porto Alegre, Brazil. Specimen DGM 672-Pb is part of the collection of the Museu de Ciências da Terra (MCT) of the Departamento Nacional de Produção Mineral (DNPM) in Rio de Janeiro, Brazil.

\section{SYSTEMATIC PALEOBOTANY}

Incertae sedis

\section{Paulophyton Dolianiti, 1954 emend.} Leguizamón \& Archangelsky, 1981

Remarks. The genus Paulophyton was created by Dolianiti (1954) for plant fragments with Psilophyton-like habit found in an Early Carboniferous flora from the Parnaíba Basin, NE Brazil (Table 1). He described the type species, P. sommeri Dolianiti, mainly based on fertile fragments. Kräusel (1957) described another species ( $P$. jongmansi Kräusel) from Namurian deposits in Germany. Leguizamón \& Archangelsky (1981) recognized two more species (P. llanensis Leguizamón \& Archangelsky and P. cuyanum Leguizamón \& Archangelsky) from Late Carboniferous deposits of Argentina, and emended the generic diagnosis adding details about the sterile portions and spores. Leguizamón \& Archangelsky (1981) considered Kegelidium lamegoi Dolianiti, 1954 to be so similar to Paulophyton that they included it into their diagnosis (op. cit., p. 103, 104). Recent revision of Dolianiti's material, made by the authors, shows that Kegelidium and Paulophyton are very different fructifications probably belonging to distinct plant groups (Iannuzzi, 1994; Iannuzzi \& Pfefferkorn, 2014). Iannuzzi $(1994,1996)$ proposed a reconstruction of the genus Paulophyton based on the type-species, Paulophyton sommeri, in order to clarify the habit of this plant which is included here as Figure 2. In addition, there is a fifth unnamed species (Paulophyton sp. 1 in Tables 1 and 2) known from the same beds as the type species in the Parnaíba Basin (Iannuzzi, 1994, 1996), and a sixth species (P. argentinus in Tables 1 and 2), originally described by Carrizo (unpublished dissertation, 1998) to Early Carboniferous deposits of Argentina, which was recently published by Carrizo \& Azcuy (2015). Paulophyton sommeri has also been recognized in the Siripaca Formation, on the Copacabana Peninsula, Bolivian Altiplano (Iannuzzi et al., 1999).

\section{Paulophyton sommeri Dolianiti, 1954}

(Figures 2, 3)

Synonymy (of material published from Paracas):

(?) Planta incertae sedis Seward, 1922, p. 282, pl. 13, fig. 10.

(?) Rhodea sp. Steinmann, 1929, p. 32, fig. 31.

Description of sterile specimens. All sterile specimens consist of leafless, short, narrow (thin), rigid, and erect axes (Figures 2F-I). Specimen RPT-89-37-D represents probably the upper part of the main axis that bears alternately two secondary axes. The principal axis is incomplete, without ornamentation, and $18.9 \mathrm{~mm}$ long. Its width varies from the base $(0.7 \mathrm{~mm})$ to the top $(0.5 \mathrm{~mm})$. The two secondary axes are $0.4 \mathrm{~mm}$ wide and are broken off (or disappear) in the matrix close to the branching point.

Specimen RPT-89-37-F and MP-Pb 4032 are interpreted as lateral portions of branching systems (axes of the third to fifth order). The dichotomous branching system of specimen RPT-89-37-F divides three times in acute angles. The basal axis and those of the next order are $0.4 \mathrm{~mm}$ wide. The most complete axis attached to the basal axis is $6.4 \mathrm{~mm}$ long. All terminal axes are $0.3 \mathrm{~mm}$ wide and a complete one is $3.6 \mathrm{~mm}$ long. There are indications that another dichotomous fork may be present on one of the axes. Specimen MP-Pb 4032 shows three incompletely preserved penultimate axes, $0.3-0.5 \mathrm{~mm}$

Table 1. Countries and ages of known occurrences of genus Paulophyton.

\begin{tabular}{lll}
\hline P. sommeri Dolianiti, 1954 & Brazil & late Visean \\
P. jongmansi Kräusel, 1957 & Germany & Namurian \\
P. cuyanum Leguizamón \& Archangelsky, 1981 & Argentina & Bashkirian-early Moscovian \\
P. llanensis Leguizamón \& Archangelsky, 1981 & Argentina & Bashkirian-early Moscovian \\
Paulophyton sp. 1 Iannuzzi, 1994, 1996 & Brazil & late Visean \\
P. argentinus Carrizo, 1998; Carrizo \& Azcuy, 2015 & Argentina & Tournaisian-late Visean \\
P. sommeri Iannuzzi et al., 1999 & Bolivia & late Visean-early Serpukhovian \\
P. sommeri [this paper] & Peru & late Visean-early Serpukhovian \\
\hline
\end{tabular}



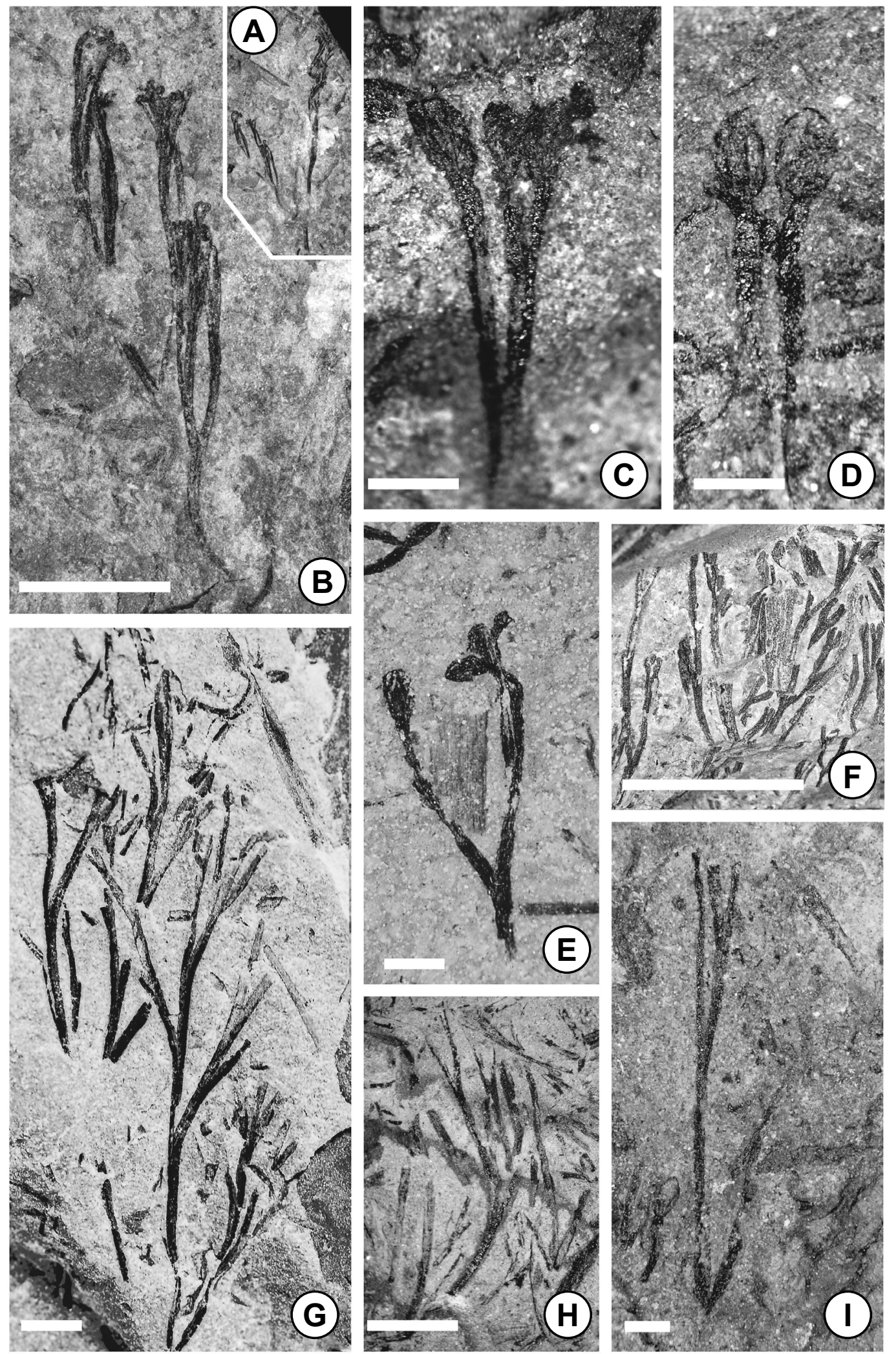

Figure 2. Photographs of Paulophyton from Paracas, Peru (Figures A-D, F, H, I) and the paratype of Paulophyton sommeri (Figure E) from Brazil. A, RPT-89-145, natural size. B, RPT-89-145, detail of sporangia-bearing branches with recurved terminal sporangia. C, RPT-89-37A, detail of terminal branching with three sporangia, two parallel marks are visible on sporangium on left. D, RPT-89-37C, two terminal branches with sporangia, two parallel marks are visible on sporangium on left. The apparent connection of the axes just below the sporangia is a preservational feature. E, DGM 672-Pb, paratype of Paulophyton sommeri from Poti Formation, Parnaíba Basin, NE Brazil, studied by Dolianiti (1954). F, RPT-89-37E, sterile terminal branches ending in rounded apices. G, MP-Pb 4032, monopodial branching pattern. H, RPT-89-37H, detail of distal dichotomous branching pattern, tips of axes not preserved. I, RPT-89-37G, distal dichotomous branching pattern, tips of axes not preserved. Scale bars: $B, H=5 \mathrm{~mm} ; C, D, E, I=1 \mathrm{~mm} ; F=10 \mathrm{~mm} ; \mathrm{G}=2.5 \mathrm{~mm}$. 
wide, and bears alternating incomplete ultimate axes (Figure $2 \mathrm{G})$. The most complete penultimate axis is $22.5 \mathrm{~mm}$ long, bearing at acute angles four to five dichotomously branched ultimate axes, 0.3-0.4 $\mathrm{mm}$ wide. The ends of these axes are not preserved.

Specimen RPT-89-37-E, G, and H represent distal parts of a branching system. Specimen RPT-89-37-E consists of three axes with a similar width of $0.2-0.3 \mathrm{~mm}$ (Figure 2F). The bottom axis is incomplete and forks at an acute angle giving rise to two axes that are 1.6 and $1.2 \mathrm{~mm}$ long and end in rounded apices. Specimen RPT-89-37-G is represented by axes that divide three times at acute angles constituting a dichotomous branching system (Figure 2I). From the basal fork arise two axes of $0.3 \mathrm{~mm}$ width. One of these is complete, reaching $6.5 \mathrm{~mm}$ in length and giving rise to two axes of 0.2 and $0.3 \mathrm{~mm}$ width. The most complete penultimate axis is 2.5 $\mathrm{mm}$ long and forks at the top into two incomplete axes of 0.3 and $0.2 \mathrm{~mm}$ width. Specimen RPT-89-37-H is represented by axes that divide four to five times at acute angles (Figure 2H). The basal fork gives rise to two axes that are $0.4 \mathrm{~mm}$ wide. Only one of these is complete, reaching $6.6 \mathrm{~mm}$ in length and forking into two axes $0.4 \mathrm{~mm}$ wide. The most complete nextorder axis is $2.4 \mathrm{~mm}$ long and gives rise to two penultimate axes that are $0.3 \mathrm{~mm}$ wide. The most complete penultimate axis is $3.3 \mathrm{~mm}$ long and forks twice giving rise to three ultimate incomplete axes that are $0.3 \mathrm{~mm}$ wide.

Description of fertile specimens. Fertile specimens are represented by short, narrow, leafless axes bearing small terminal sporangia (Figures 2A-D). Several specimens constitute short dichotomously branching systems in which the axes divide at acute angles.

The most complete specimen, RTP-89-145, represents parts of a possible main axis that bears alternately two secondary axes (Figures 2A,B). The main axis is fragmentary, without ornamentation, $34.0 \mathrm{~mm}$ long, and $0.5-0.7 \mathrm{~mm}$ wide.
The basalmost secondary axis is incomplete, $0.4 \mathrm{~mm}$ wide, and gives rise to two clusters of dichotomous fertile axes. The proximal cluster is represented by axes with similar width, about 0.3-0.4 $\mathrm{mm}$, that divide three times with acute angles. The basalmost axis is $3.2 \mathrm{~mm}$ long and forks at the top giving rises to two penultimate axes of 3.6 and $2.5 \mathrm{~mm}$ length that fork at the top giving rise to four ultimate fertile axes. The distal cluster (the best preserved) is represented by incomplete axes that are 0.3-0.4 mm wide and divide apparently three times at very small angles, giving rise to ultimate fertile axes. All preserved ultimate axes ending in the recurved tips that bear one sporangium each (Figure 2B). The sporangia are oval in shape, and $0.6 \mathrm{~mm}$ long and $0.4-0.5 \mathrm{~mm}$ wide.

The axis of specimen RPT-89-37-A divides twice and bears three sporangia (Figures 2C, 3A). The basalmost axis is incomplete and forks at the top, resulting in axes that are 1.3 and $1.4 \mathrm{~mm}$ long and also divide. Four axes result from this second fork, one of which is not preserved but its presence is indicated by its insertion point (Figure $3 \mathrm{~A}$ ). The three axes are $1.1,1.1$, and $0.8 \mathrm{~mm}$ long, bearing one terminal sporangium each. All axes have a similar width of $0.2-0.3 \mathrm{~mm}$. Two of them show continuous narrow median lines, filled with coalified material, partially preserved which are interpreted herein as being remains of their vascular bundles (Figure 3A). The sporangia are oval in shape, $1.0,0.9$, and $1.0 \mathrm{~mm}$ long by $0.6,0.5$, and $0.4 \mathrm{~mm}$ wide, respectively, and are arranged in pairs. The sporangia have two longitudinal marks on their surfaces (Figures 2C, left sporangium, and $3 \mathrm{~A}$ ).

Specimen RPT-89-37-C consists of one terminal axis which forks at least once, giving rise to two ultimate axes, all of them with approx. $0.3 \mathrm{~mm}$ width (Figures 2D, 3B). The most complete axis is $2.1 \mathrm{~mm}$ long. All axes show a continuous narrow median line, filled with coalified material, that probable corresponds to the central vascular bundle (Figure 3B). The two ultimate axes are essentially complete

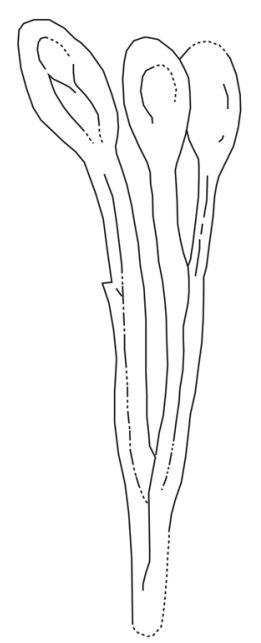

A

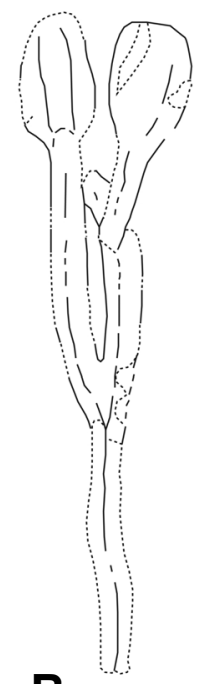

B

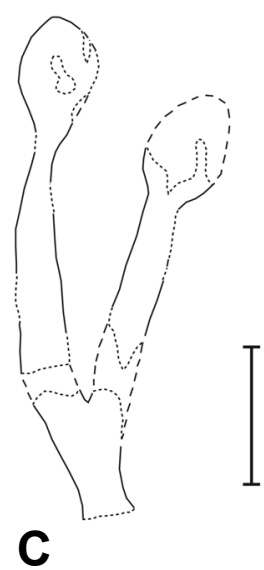

Figure 3. Drawings of fertile specimens of Paulophyton sommeri Dolianiti from Paracas, Peru. All three occur on sample RPT-89-37. Scale bar $=1 \mathrm{~mm}$. 
(the right one is broken, Figure 3B) and bear one terminal sporangium each. The sporangia are oval, $1.0 \mathrm{~mm}$ long and 0.6 $\mathrm{mm}$ wide. They show longitudinal marks. In one sporangium (Figures 2D, left sporangium, and 3B) these marks appear like a pair of parallel lines, arising at the base of the sporangium and almost reaching the top (Figure 3B).

Specimen RPT-89-37-B consists of two very fragmentary axes with terminal sporangia. The basal axis is not completely visible but presumably forks giving rise to the two ultimate parallel axes with similar width $(0.3-0.4 \mathrm{~mm})$, and 2.3 and $2.0 \mathrm{~mm}$ length respectively. The most complete terminal sporangium preserved is oval in shape, $0.9 \mathrm{~mm}$ long and 0.6 $\mathrm{mm}$ wide (Figure 3C).

Specimen RPT-89-37-G1 consists of only one axis. The axis is $0.3 \mathrm{~mm}$ wide and bears an oval-shaped terminal sporangium, $1.1 \mathrm{~mm}$ long and $0.6 \mathrm{~mm}$ wide, which does not show any lines or marks.

\section{DISCUSSION}

The material from Paracas is similar to Paulophyton in its three-dimensional branching system with an alternation between dichotomous and pseudomonopodial patterns of distal leafless axes that can bear terminal oval-shaped sporangia. On the specific level, the material of Paulophyton from Paracas belongs probably to $P$. sommeri, which is the type species of the genus. The specimens studied resemble more P. sommeri in terms of the range of length and width of sporangia, orientation of sporangia, arrangement of secondary axes and division pattern of terminal axes, than the other species (Table 2). The recurved tips of the sporangiabearing ultimate axes found only in specimen RTP-89-145 (Figure 2B) seem to be a feature resulting of a taphonomic bias caused by decay and/or immaturity of sporangia. The sporangia of this specimen are not well preserved and represent the smallest ones $(0.6 \times 0.4-0.5 \mathrm{~mm})$ observed among the material analyzed, suggesting that some kind of alteration or degradation could have occurred. Because of these considerations, the possible recurved orientation of sporangia is not being considered herein as a definitive diagnostic feature of the Peruvian material.

In fact, the assignment of any material to a species of this genus is not an easy task. A comparison of character states in the different species (Table 2) shows the range of variability as well as the similarities between the taxa. A significant overlap of diagnostic features can be observed between different species.

It appears that material belonging to Paulophyton was recognized at Paracas by early workers (Seward, 1922; Steinmann, 1929). However, they did not see fertile material and used the name Rhodea or incertae sedis. Read (1938) figured a specimen under the name "Aphlebia australis" Read (1938, fig. 6) that resembles Paulophyton. However, visual inspection of the illustrated specimen housed in the NMNH of Smithsonian Institution, Washington, revealed that the specimen is badly illustrated and represents an incomplete, probable pteridospermous root system.

\section{Paulophyton-plant}

The small size and terminal arrangement of sporangia in Paulophyton is reminiscent of some Rhyniophytes. Nevertheless, Paulophyton is a more advanced plant exhibiting a regular dichotomous to pseudomonopodial branching system (Figure 4) with a strong principal axis in its lower parts. This main axis can be more than $11 \mathrm{~cm}$ long and $6 \mathrm{~mm}$ wide as shown by Brazilian specimens (Iannuzzi, 1994). Paulophyton is similar to Psilophyton in its three-dimensional branching system with leafless axes and terminal sporangia. However, Paulophyton differs from Psilophyton in having a more regular branching system with a pseudomonopodial arrangement of the principal axis and an alternation between dichotomous and pseudomonopodial systems on lateral branches. Besides, the terminal sporangia are smaller and do not have an obvious

Table 2. Comparison of character states of species of genus Paulophyton. Abbreviations: P, pseudomonopodial; $\mathbf{D}$, dichotomous or sympodial.

\begin{tabular}{|c|c|c|c|c|c|c|}
\hline Species & Habit & $\begin{array}{l}\text { Arrangement of } \\
\text { secondary axis }\end{array}$ & $\begin{array}{l}\text { Division pattern of } \\
\text { terminal axis }\end{array}$ & $\begin{array}{l}\text { Orientation of } \\
\text { sporangia }\end{array}$ & $\begin{array}{l}\text { Length of } \\
\text { sporangia } \\
(\mathrm{mm})\end{array}$ & $\begin{array}{l}\text { Width of sporangia } \\
\qquad(\mathrm{mm})\end{array}$ \\
\hline P. sommeri & $\mathrm{P}$ & $\begin{array}{l}\text { alternate in pairs, } \\
\text { probably spiral }\end{array}$ & P-D & erect & $0.8-1.2$ & $0.5-0.9$ \\
\hline P. jongmansi & $\mathrm{P}$ & $\begin{array}{l}\text { alternate to } \\
\text { sub-opposite }\end{array}$ & P-D & recurved & $2.0-3.0$ & $1.5-2.2$ \\
\hline P. cuyanum & $\mathrm{P}$ & $\begin{array}{c}\text { alternate and } \\
\text { probably spiral }\end{array}$ & $\mathrm{D}$ & erect & $0.6-0.9$ & $0.4-0.5$ \\
\hline P. llanensis & $\mathrm{P}$ & bilateral & $\mathrm{D}$ & recurved & $1.6-2.2$ & $0.4-2.0$ \\
\hline Paulophyton sp. 1 & $\mathrm{P}$ & $\begin{array}{c}\text { alternate in pairs, } \\
\text { probably spiral }\end{array}$ & P-D & circinate & $0.6-0.9$ & $0.4-0.5$ \\
\hline P. argentinus & $\mathrm{P}$ & alternate and spiral & P-D & pendulous & $1.8-2.8$ & 1.1 \\
\hline This material & $\mathrm{P}$ & alternate & P-D & erect to recurved? & $0.6-1.0$ & $0.4-0.6$ \\
\hline
\end{tabular}




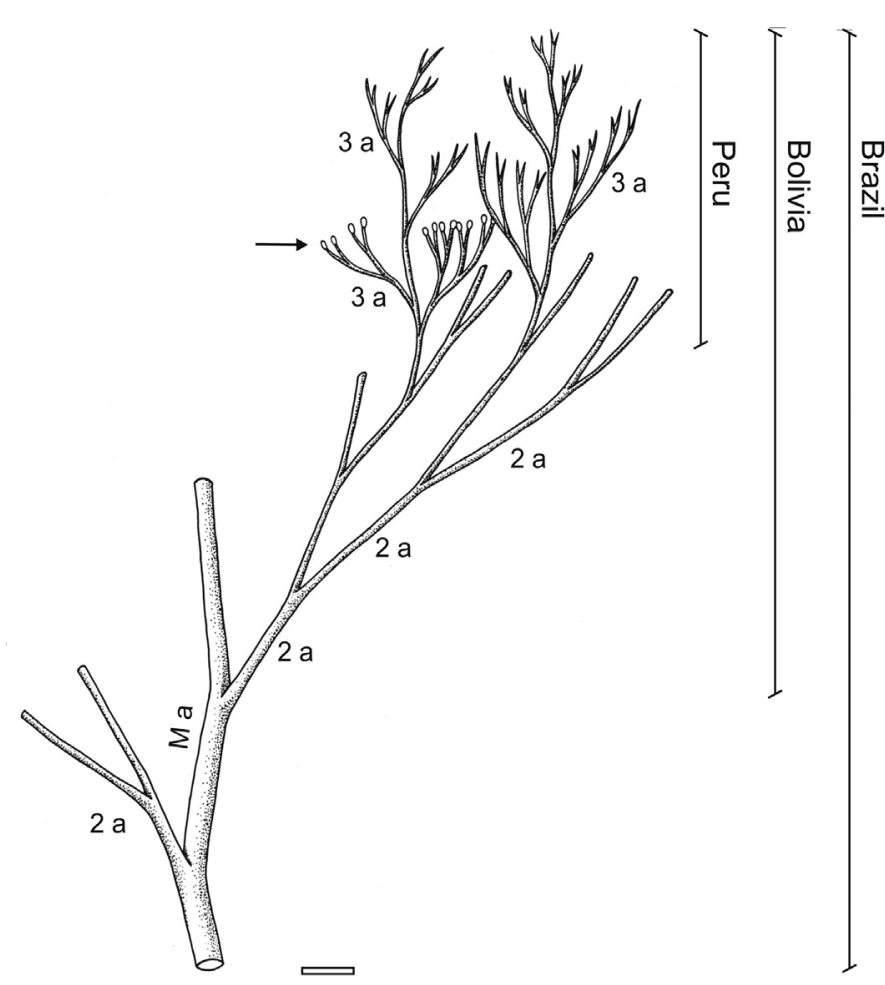

Figure 4. Partial reconstruction of branching pattern of Paulophyton sommeri Dolianiti based on material from Brazil, Bolivia and Peru (modified from lannuzzi, 1994, 1996). Note the sporangia (arrow) inserted in the top of terminal erect axes. Legend: Ma, main axis; $2 a$, second order axis; $\mathbf{3 a}$, third order axis. Scale bar $=1 \mathrm{~cm}$.

dehiscence mechanism. Sporangia have not been found open or separated from the plant.

Paulophyton is similar to terminal fertile portions of Ibyka from the Middle Devonian (Skog \& Banks, 1973) in respect to size, apical attachment of sporangia, and arrangement in pairs on terminal axes. However, the sterile portions of Paulophyton have a totally different appearance from those of Ibyka. The branching system of Paulophyton is pseudomonopodial with an alternation between dichotomous and pseudomonopodial systems on lateral branches while in Ibyka it is basically monopodial (Skog \& Banks, 1973). Also, in Paulophyton the terminal sterile axes never show recurved tips as seen in Ibyka. They always consist of short, rigid, and terete axes (Figures 2F-H).

Paulophyton resembles the vegetative and fertile portions of genus Chlidanophyton Gensel emend. Hilton from the latest Devonian-earliest Carboniferous of North America and England (Hilton, 1999) in terms of the pseudomonopodial branching system consisting of three orders of leafless axes arranged in 3D and possessing alternately arranged dichotomous ultimate appendages, with those on the fertile branches bearing ovoid terminal sporangia. In the meantime, Chlidanophyton is also distinguished by having dichotomous appendages (Aphlebiae-type) located on opposite sides of the base of each second to third-order branch axis, the sporangia with longitudinal dehiscence, and an epidermal pattern that is obliquely striated, both features not present in Paulophyton.
In addition, Paulophyton appears to be similar to Rhodea, a Carboniferous plant in which pinnules look like a branch system. However, Rhodea has a planated frond without lamina, while Paulophyton has a three-dimensional structure.

Finally, Paulophyton is similar to some pteridosperm compressions described by Scott \& Meyer-Berthaud (1985) as Tristichia ovensi Scott \& Meyer-Berthaud from the Dinantian of Scotland. Nevertheless, Paulophyton shows a pseudomonopodial branching system, with the presence of one well-developed principal axis, while compressed specimens of $T$. ovensi exhibit a dichotomous branching system even in basal parts. Small male organs (Scott \& MeyerBerthaud, 1985) associated with $T$. ovensi remind one of some aspects of Paulophyton's fertile parts. However, Paulophyton has smaller sporangia, terminally inserted while those of $T$. ovensi are laterally attached.

\section{CONCLUDING REMARKS}

In many respects, Paulophyton shows the closest morphological similarities with Trimerophytes and Cladoxylaleans of the Devonian. However, sporangia of Paulophyton are small (only $1 \mathrm{~mm}$ long) and nobody has found one of these sporangia clearly open as one might expected if a true mechanism of dehiscence existed in this plant. Short parts of axes are always attached to the sporangia even if the material is very fragmentary. Leguizamón \& Archangelsky (1981) were able to macerate sporangia of their material but did not see any dehiscence line. These observations seem to indicate that the sporangia had neither a dehiscence mechanism nor were they shed as an isolated entity.

On the other hand, the sporangia often show two parallel lines (rarely a single one), referred to by Dolianiti (1954) as ridges longitudinally detached from the main body of each sporangium (Figures 2C-D). At first glance, one might interpret them as folds that formed when the sporangium collapsed. Carrizo \& Azcuy (2015) have recently interpreted these longitudinal marks as possible lines of rupture related to a true dehiscence mechanism. However, these two lines always seem to be spaced at a distance that is equivalent to the diameter of the axis that carries them. In some specimens the space between the two lines is either elevated or depressed and in others the rock matrix of this area has broken away indicating that this central part of the sporangium is different from the outer parts. The specimen DGM 672-Pb (Figure 2E, paratype of Paulophyton sommeri studied by Dolianiti, 1954) shows in one of its sporangia that the axis seems to continue inside the sporangium almost to the tip (Figure 2E), the highest sporangium at right side. This feature could be interpreted as the real extension of the axis within the body of the sporangium.

Iannuzzi et al. (1999, p. 25) interpreted these structures as an indication of a central columnella that extended for more than two thirds of the length of the sporangium. It is worth noting that a columnella is known only in mosses and Horneophyton (Kenrick \& Crane, 1997). The possible presence of a columnella or the extension of the axis inside 
Table 3. Updated plant macrofossil data from Paracas, Peru. Symbol: * this taxon has been recently re-evaluated and became now referred to as Notorhacopteris kellaybelenensis Azcuy \& Suárez-Soruco emend. Azcuy, Carrizo \& lannuzzi, 2011 (Addendum in Azcuy et al., 2014).

\author{
LYCOPSIDS \\ Cyclostigma pacifica (Steinmann) Jongmans, 1954 \\ Tomiodendron peruvianum (Gothan) Pfefferkorn \& Alleman, 2002 in Iannuzzi \& Pfefferkorn (2002)
}

SPHENOPSIDS

Archaeocalamites radiatus Brongniart, 1828 in Steinmann (1910), Doubinger \& Alvarez Ramis (1980)

\title{
PTERIDOSPERMS
}

Diplothmema gothanica (Dolianiti) Iannuzzi, 2002 in Iannuzzi \& Pfefferkorn (2002)

Fryopsis frondosa (Goeppert) Wolfe, 1962 in Iannuzzi \& Pfefferkorn (2002)

Nothorhacopteris kellaybelenensis Azcuy \& Suárez-Soruco in Iannuzzi et al. (1998)*

Obandotheca laminensis Erwin, Pfefferkorn \& Alleman, 1994

Oclloa cesariana Erwin, Pfefferkorn \& Alleman, 1994

?Sphenopteridium intermedium (Feistmantel) Rigby, 1973 in Iannuzzi et al. (1998)

Triphyllopteris boliviana Iannuzzi, Rösler \& Suárez-Soruco, 1993 in Iannuzzi et al. (1998)

Aneimites sp. in Iannuzzi \& Pfefferkorn (2002)

\section{INCERTAE SEDIS}

Paulophyton sommeri [this paper]

the sporangia and the simple morphology are two potential indicators that Paulophyton may be the representative of a group that has otherwise not yet been recognized in the Carboniferous. Until further and better-preserved material is discovered, Paulophyton remains a distinct morphogenus of Carboniferous age whose systematic position has yet to be determined.

This new occurrence of Paulophyton sommeri does not expand the list of taxa present in Paracas (Table 3), but further increases the correlation between this flora and other South American ones belonging to the Paracas floral belt, i.e. from Bolivia and northeastern Brazil, where this species had been recorded previously (Dolianti, 1954; Iannuzzi et al., 1999). This reinforces the existence of this floral belt in the northcentral region of the continent composed of some taxa that coexisted for a short time interval in the Mississippian.

Despite being known mainly from western Gondwana, Paulophyton has a long and interesting history of dispersion through this area during Carboniferous times. Apparently, Paulophyton originated in northeastern Argentina, during the Tournaisian, under conditions of a cool-to-warm temperate climate (Carrizo \& Azcuy, 2015). In the late Visean, during a warming time (= Paracas greenhouse interval of Pfefferkorn et al., 2014), the genus was dispersed northward, occupying areas with warm temperate climates, e.g. Peru, Bolivia and northern Brazil, which resulted in the appearance of the species P. sommeri (Dolianiti, 1954; Iannuzzi et al., 1999; this paper). Towards the end of the Mississippian (early-to-late Serpukhovian), it dispersed once more, now toward the tropics, being recorded in Germany by the species P. jongmansi (Kräusel, 1957). Perhaps, it followed movements of climate belts that occurred as a consequence of a glacial event that occurred in South America towards the end of the Serpukhovian (Césari et al., 2011). After this late Mississippian glacial interval, Paulophyton returned to appear in northeastern Argentina, living under the same conditions of temperate climate in which it originally arose, and where it diversified into two species, e.g. P. cuyanum and P. llanensis during the early Pennsylvanian (Leguizamón \& Archangelsky, 1981). These are the last known records of this unusual Carboniferous plant.

\section{ACKNOWLEDGMENTS}

We thank the leadership of the Reserva National de Paracas, the Instituto Nacional de Recursos Naturales, and the Ministerio de Ambiente for permissions and support during our research at the Paracas site. We acknowledge partial support for this research by CONCYTEC to V.A., the National Science Foundation (EAR-8916826), and the University of Pennsylvania Research Foundation to H.W.P., and CAPES (Coordenação de Aperfeiçoamento de Pessoal de Nível Superior, Process no. BEX 0461/03-2) and CNPq (Conselho Nacional de Pesquisa, Process no. PQ 309211/2013-1) to R.I. Also, we would like to thank the reviewers H.A. Carrizo and R. Rohn for their fruitful suggestions. R. Jones helped with the photography and $\mathrm{D}$. Wang and $\mathrm{B}$. Trenk assisted with the rendition of figures. 


\section{REFERENCES}

Alleman, V. 1985. Paleontología de los carbones paleozoicos peruanos. In: SIMPOSIO NACIONAL DEL CARBÓN, 1, 1985. Actas, Lima, SGP, p. 1-12.

Alleman, V. \& Pfefferkorn, H.W. 1988. Licópodos de Paracas: significación geológica y paleoclimatológica. Boletín de la Sociedad Geológica del Perú, 78:131-136.

Azcuy, C.L. 1991. Palinología de la Formación Ambo (Carbonífero inferior), Perú. Ameghiniana, 28:200.

Azcuy, C.L.; Carrizo, H.A. \& Iannuzzi, R. 2011. Frondes rhacopterídeas del Neopaleozoico de América del Sur: taxonomía y evolución morfológica. Acta Geológica Lilloana, 23:3-26.

Azcuy, C.L.; Carrizo, H.A. \& Iannuzzi, R. 2014. Adenda: Azcuy C. L., Carrizo H. A., Iannuzzi R. 2011. "Frondes rhacopterídeas del Neopaleozoico de América del Sur: taxonomía y evolución morfológica". Acta Geológica Lilloana, 26:199-201.

Azcuy, C.L. \& di Pasquo, M.M. 2005. Early Carboniferous palynoflora from the Ambo Formation, Pongo de Mainique, Peru. Review of Palaeobotany and Palynology, 134:153-184. doi: 10.1016/j.revpalbo.2004.12.004

Azcuy, C.L. \& di Pasquo, M.M. 2006. Additional systematic information of the Early Carboniferous palynoflora from the Ambo Formation, Pongo de Mainique, Peru. Revista Brasileira de Paleontologia, 9:15-26. doi: 10.4072/rbp.2006.1.05

Carrizo, H.A. 1998. Estudio de floras eocarboniferas de Argentina y su comparación con las de otras regiones relacionadas. Facultad de Ciencias Naturales, Universidad Nacional de Salta, Ph.D. Thesis, 304 p. (unpublished)

Carrizo, H.A. \& Azcuy, C.L. 2015. Floras neodevónicaseocarboniferas de Argentina. Consideraciones sobre las fitozonas del Carbonifero Tardio del centro-oeste argentino. Tucumán, Fundación Miguel Lillo, 292 p. (Opera Lilloana 49).

Césari, S.N.; Limarino, C.O. \& Gulbranson, E.L. 2011. An upper Paleozoic bio-chronostratigraphic scheme for the western margin of Gondwana. Earth Science Reviews, 106:149-160. doi: 10.1016/j.earscirev.2011.01.012

Dolianiti, E. 1954. A flora do Carbonifero Inferior de Teresina, Piauí. Rio de Janeiro, Departamento Nacional da Produção Mineral, Divisão de Geologia e Mineralogia, 56 p. (Boletim 148).

Doubinger, J. \& Alvarez Ramis, C. 1980. Nota sobre la flora de la Formación Ambo, Carbonífero Inferior del Perú. In: CONGRESO ARGENTINO DE PALEONTOLOGÍA Y BIOESTRATIGRAFÍA, 2, CONGRESOLATINOAMERICANO DE PALEONTOLOGÍA, 1, 1980. Actas, Buenos Aires, APA, p. $89-101$.

Erwin, D.M.; Pfefferkorn, H.W. \& Alleman, V. 1994. Early seed plants in the Southern Hemisphere: I. Associated ovulate and microsporangiate organs from the Carboniferous of Peru. Review of Palaeobotany and Palynology, 80:19-38. doi: 10.1016/00346667(94)90090-6

Hilton, J. 1999. A Late Devonian plant assemblage from the Avon Gorge, west England: taxonomic, phylogenetic and stratigraphic implications. Botanical Journal of the Linnean Society, 129:1-54. doi: 10.1006/bojl.1998.0209

Iannuzzi, R. 1994. Reavaliação da Flora Carbonífera da Formação Poti, Bacia do Parnaíba. Programa de Pós-graduação em Geologia Sedimentar, Universidade de São Paulo, Dissertação de Mestrado, $232 \mathrm{p}$.

Iannuzzi, R. 1996. Paulophyton spp.: formas devonianas relictuais nas floras do Carbonífero da América do Sul? In: SIMPÓSIO
SUL-AMERICANO DO SILURO-DEVONIANO, 1, 1996. Anais, Ponta Grossa, UEPG, p. 337-344.

Iannuzzi, R.; Díaz-Martínez, E. \& Suárez-Soruco, R. 1999. Los elementos florísticos de la Formación Siripaca (Grupo Ambo, Bolivia) y su contexto bioestratigráfico. Pesquisas, 26:21-40.

Iannuzzi, R. \& Pfefferkorn, H.W. 2002. A pre-glacial, warm-temperate floral belt in Gondwana (late Visean, Early Carboniferous). Palaios, 17:571-590. doi: 10.1669/0883-1351(2002)017<0571:APGWT $F>2.0 . C O ; 2$

Iannuzzi, R. \& Pfefferkorn, H.W. 2014. Re-interpreting Kegelidium lamegoi Dolianiti, a microsporangiate organ from the Poti Formation (Late Visean), Parnaíba Basin, northeastern Brazil. Comunicações Geológicas, 101:451-453.

Iannuzzi, R.; Pfefferkorn, H.W.; Díaz-Martínez, E.; Alleman, V. \& Suárez-Soruco, R. 1998. La flora eocarbonífera de la Formación Siripaca (Grupo Ambo, Bolivia) y su correlación con la Flora Paracas (Grupo Ambo, Perú). Boletín de la Sociedad Geológica del Perú, 88:39-51.

Jongmans, W.J. 1954. The Carboniferous flora of Peru. Bulletin of the British Museum (Natural History), Geology, 2:189-224.

Kenrick, P. \& Crane, P.R. 1997. The origin and early diversification of land plants: a cladistic study. Washington, Smithsonian Institution Press, 441 p.

Kräusel, R. 1957. Paulophyton jongmansi n. sp. eine Pflanze altertümlichen Baues aus dem Namur des Ruhrgebietes. Mededeelingen van de Geologische Stichting, 11:21-25.

Leguizamón, R. \& Archangelsky, S. 1981. Dos nuevas primofilices carbónicas de las provincias de La Rioja y San Juan. Ameghiniana, 18:103-112.

Nuñez del Prado, H. 1991a. Análisis sedimentológico preliminar y paleoambiente de sedimentación de la Serie carbonífera de Paracas (Ica-Perú). In: CONGRESO PERUANO DE GEOLOGÍA, 7, 1991. Resúmenes extendidos, Lima, SGP, p. $45-48$.

Nuñez del Prado, H. 1991b. Preliminary sedimentological analysis and depositional system of the Carboniferous at Paracas Peninsula, Peru. In: INTERNATIONAL CONGRESS ON THE CARBONIFEROUS AND PERMIAN GEOLOGY AND STRATIGRAPHY, 12, 1991. Abstracts, Buenos Aires, CONICET, p. 63-64.

Pfefferkorn, H.W. \& Alleman, V. 1989. New climatic belt in Carboniferous of the southern hemisphere. In: INTERNATIONAL GEOLOGICAL CONGRESS, 28, 1989. Abstracts, 2, Washington, D.C., USA, p. 602.

Pfefferkorn, H.W.; Alleman, V. \& Iannuzzi, R. 2014. A greenhouse interval between icehouse times: climate change, long-distance plant dispersal, and plate motion in the Mississippian (late Visean-earliest Serpukhovian) of Gondwana. Gondwana Research, 25:1338-1347. doi: 10.1016/j.gr.2013.08.022

Read, C.B. 1938. The age of the Carboniferous strata of the Paracas Peninsula, Peru. Journal of the Washington Academy of Sciences, 28:396-404.

Scott, A.C. \& Meyer-Berthaud, B. 1985. Plants from the Dinantian of Foulden, Berwickshire, Scotland. Transactions of the Royal Society of Edinburgh: Earth Sciences, 76:13-20. doi: 10.1017/ S0263593300010245

Seward, A.C. 1922. On a collection of Carboniferous plants from Peru. Quarterly Journal of the Geological Society London, 78:278-284. doi: 10.1144/GSL.JGS.1922.078.01-04.10 
Skog, J.E. \& Banks, H.P. 1973. Ibyka amphikoma, gen. et sp. n., a new protoarticulate precusor from the late Middle Devonian of New York State. American Journal of Botany, 60:366-380. doi: 10.2307/2441203

Steinmann, G. 1910. Über die Steinkohlenformation in Südamerika. Gelogische Rundschau, 1:50-51.
Steinmann, G. 1929. Geologie von Peru. Heidelberg, Carl Winters Verlag, 448 p. (Spanish edition, 1930).

Received in July, 2015; accepted in November, 2015. 